\title{
Soil Chemistry Factors Confounding Crop Salinity Tolerance-A Review
}

\author{
Pichu Rengasamy \\ School of Agriculture, Food and Wine, Prescott Building, Waite Campus, The University of Adelaide, Adelaide, \\ 5005 SA, Australia; pichu.rengasamy@adelaide.edu.au
}

Academic Editor: Matthew Gilliham

Received: 26 August 2016; Accepted: 25 October 2016; Published: 29 October 2016

\begin{abstract}
The yield response of various crops to salinity under field conditions is affected by soil processes and environmental conditions. The composition of dissolved ions depend on soil chemical processes such as cation or anion exchange, oxidation-reduction reactions, ion adsorption, chemical speciation, complex formation, mineral weathering, solubility, and precipitation. The nature of cations and anions determine soil $\mathrm{pH}$, which in turn affects crop growth. While the ionic composition of soil solution determine the osmotic and ion specific effects on crops, the exchangeable ions indirectly affect the crop growth by influencing soil strength, water and air movement, waterlogging, and soil crusting. This review mainly focuses on the soil chemistry processes that frustrate crop salinity tolerance which partly explain the poor results under field conditions of salt tolerant genotypes selected in the laboratory.
\end{abstract}

Keywords: soil chemistry; saline soils; dispersive soils; soil physical conditions

\section{Introduction}

The aqueous components of a soil at different water contents in the field determine the abiotic stress experienced by plants during their growth, consequently affecting the crop yield [1]. In salt-affected soils, the total concentration of dissolved salts in soil solutions, generally measured as the electrical conductivity (EC) of the soil solutions, is considered as the primary criterion affecting the yield (e.g., [2]). Thus, most of the research on crop salinity tolerance has focussed on EC of soil solutions inducing osmotic pressure affecting water uptake by plants and the accumulation of specific ions in the plant over a period of time leading to ion toxicity or ion imbalance [3]. Because of the common opinion that sodium chloride $(\mathrm{NaCl})$ is the predominant salt in saline soils, ionic effects of sodium $(\mathrm{Na})$ and chloride $(\mathrm{Cl})$ have received more attention.

However, the composition of electrolytes, in addition to the total concentration, determines the multi-phase equilibria involving: (1) the solid phase comprising clay minerals and other inorganic and organic materials, (2) the liquid phase comprising soil water, (3) the gaseous phase comprising mainly oxygen and carbon dioxide, and (4) the complex exchange phase [4,5]. During crop growth in the field soil water fluctuates from high to very low levels and the chemical equilibria become more complex. Exchange reactions are determined by the nature of cations and anions, and as a result soil physical conditions are altered leading to the limitations to crop growth caused by increased soil strength and reduced water and air movement. Plant roots need a well-hydrated and well aerated soil environment of low osmotic pressure, with adequate nutrients and low toxicity. Soil $\mathrm{pH}$, which depends on the composition of cations and anions and its relation with $\mathrm{pE}$ (electron activity related to redox potential), is changed by soil water regime, control solubility, and precipitation reactions. These processes result in the toxicity and deficiency of macro and micro- nutrient elements. Variations in soil chemistry impact on most of the plant requirements: soil structure, osmotic potential of the soil solution, soil aeration, and the presence of toxic ions. Thus 'salinity stress' is complicated by many 
soil chemical processes. This review addresses the soil chemistry factors including chemical reactions and composition of soil solution interfering with crop salinity tolerance. It is asserted here that these factors could be partly responsible for the marked differences in the response to salinity found between laboratory and field grown plants, although a detailed discussion of these differences is not part of this review.

\section{Soil Processes Affecting Soil Solution Composition}

A number of soil processes in the soil environment influence the activities of chemical species in soil water. In addition to soil components, factors related to climate and soil management also influence these processes, which are summarised in Table 1. In general, at equilibrium, a change in one parameter effects changes in all variables.

Table 1. Soil chemical processes affecting ionic composition and their chemical reactivity in soil solutions [6].

\begin{tabular}{|c|c|}
\hline Mechanism & Effects \\
\hline Ion exchange & $\begin{array}{l}\text { Clay minerals, organic matter and other amorphous compounds with inherent } \\
\text { charges (negative and/or positive) are bonded to each other in soil aggregates, with } \\
\text { the nature of the bonding determining the charge available for water interaction } \\
\text { and ion exchange. Electrolyte concentration and soil pH alter this charge. The } \\
\text { nature of cations or anions influences the ion exchange reactions changing in the } \\
\text { distribution of ions in the exchange phase and soil solution at equilibrium. }\end{array}$ \\
\hline $\begin{array}{l}\text { Dissolution and } \\
\text { precipitation }\end{array}$ & $\begin{array}{l}\text { The partial pressure of } \mathrm{CO}_{2} \text { affects the dissolution and precipitation of soil } \\
\text { carbonates and bicarbonates and ion activities including that of protons }\left(\mathrm{H}^{+}\right) \text {. } \\
\text { Organic matter controls ligand exchange and chelation resulting in ionic complexes } \\
\text { which alter the reactivity of the ions in aqueous suspensions. } \\
\text { Soil pH (proton activity), determined by the reactions of cations and anions, is the } \\
\text { primary factor in the dissolution and precipitation of inorganic minerals and } \\
\text { organic compounds. Waterlogging alters soil pH and pE (electron activity) and } \\
\text { their relationship affecting the nature of chemical species. Waterlogging also } \\
\text { decreases concentrations of oxygen in the soil solution which impact on the } \\
\text { availability of metabolic energy to root cells, therefore affecting plant growth and } \\
\text { processes like ion uptake and ion exclusion. }\end{array}$ \\
\hline Ion-pair formation & High proportions of anions result in ion-pair formation and reduced ion activity. \\
\hline Chemical speciation & $\begin{array}{l}\text { Dissolved ions in soil solutions can exist as 'free' (e.g., } \mathrm{Na}^{+} \text {, surrounded by water } \\
\text { molecules) and also as stable complexes (e.g., Al-hydroxy species). The formation } \\
\text { of complexes depends on stability constants relating to the concentration of } \\
\text { complexes and free ionic species. In soil solutions } \mathrm{pH} \text { is an important factor in the } \\
\text { formation of the complex species. The reactivity of free and complex species differs } \\
\text { according to the changes in their charge. }\end{array}$ \\
\hline Specific adsorption & $\begin{array}{l}\text { Inner-sphere complexation (or ion fixation) involves covalent bonding of ions with } \\
\text { soil particles. This phenomenon alters the particle charge available for outer-sphere } \\
\text { complexation and readily exchangeable ions. }\end{array}$ \\
\hline Microbial reactions & $\begin{array}{l}\text { Biological reactions due to soil microbes lead to the decomposition, oxidation, and } \\
\text { polymerization of organic matter, and the release of hydrophilic and hydrophobic } \\
\text { compounds controlling the chemical reactivity of soil solutions. }\end{array}$ \\
\hline
\end{tabular}

\section{Ion Exchange and Resultant Soil Structural Stability}

Soil components, including clay minerals and inorganic and organic compounds have their inherent charge $(+$ or - ), but when they are aggregated, the net charge may be different from the total charge depending on the bonding type between the components [7]. Covalent bonding between the components results in a reduction in net charge. The net charge if negative is balanced by adsorbing cations, and if positive by adsorbing anions. These adsorbed ions can change according to the concentration and the nature of the ions in solutions. Most of agricultural soils, except in tropical 
climates, have a net negative charge and cation exchange is the primary process, whereby cations are adsorbed in the exchange phase from the solutions of salt-affected soils. Water molecules react with the charge on soil particles inducing a weakening of soil aggregates, and as a consequence aggregates slake and clay particles disperse. These charges can vary according to soil $\mathrm{pH}$ [8].

The majority of salt-affected soils are dominated by sodium salts [9] and hence the exchange phase is dominated by $\mathrm{Na}$. The adsorption of $\mathrm{Na}$ in the exchange phase from soil water depends on the proportion of divalent cations in soil solution, usually indicated by the sodium adsorption ratio (SAR) measured in soil solutions. Exchangeable sodium percentage (ESP) is related to SAR, and when it exceeds a threshold level swelling and dispersion of soil clays lead to the degradation of soil physical properties resulting in reduced water and air flow, high soil strength, and soil crusting. These physical conditions severely restrict germination, root growth, and the physiological functions of crops [10].

Recent studies have shown that, in addition to sodium, exchangeable potassium and magnesium can also increase soil swelling and dispersion affecting soil physical properties [11-15]. The effects of these cations in causing swelling and dispersion are not similar, but depend on the ionicity index [14], a molecular scale geochemical parameter which estimates the relative bonding (ionic and covalent) tendency of a cation with charged particles. Swelling and dispersion increase as the ionicity of the bonding increases in the order $\mathrm{Na}>\mathrm{K}>\mathrm{Mg}>\mathrm{Ca}$. Incorporating the effects of the cationic valence in addition to the ionicity factor, Rengasamy [16] derived the dispersive powers of these cations relative to $\mathrm{Ca}$. They are: $\mathrm{Ca}=1, \mathrm{Mg}=1.7, \mathrm{~K}=25$, and $\mathrm{Na}=45$. While, in dry soils, the exchangeable cations react with water molecules inducing clay dispersion, the soluble cations present in soil water oppose the dispersive reactions because of their flocculating powers [17], and relative to $\mathrm{Na}$, they are: $\mathrm{Ca}=45$, $\mathrm{Mg}=27, \mathrm{~K}=1.8$, and $\mathrm{Na}=1$. The flocculating powers of these cations were derived on the basis of covalency factor (the degree of covalency in cation-clay bonding) and the effects of cationic valence.

Recently, Rengasamy et al. 2016 [18] proposed a new concept of "net dispersive charge" which determines the amount of clay dispersed from a dispersive soil, and is defined as:

$$
\text { Net dispersive charge }=\text { dispersive charge }- \text { flocculating charge }
$$

The dispersive charge of a soil is derived from the concentrations of exchangeable cations $\left(\mathrm{cmol}_{\mathrm{C}} \cdot \mathrm{kg}^{-1}\right)$ measured at the given soil $\mathrm{pH}$, weighted by the respective dispersive power, and is defined as:

$$
\text { Dispersive charge }\left(\mathrm{cmol}_{\mathrm{c}} \cdot \mathrm{kg}^{-1}\right)=(\mathrm{Ca})+1.7(\mathrm{Mg})+25(\mathrm{~K})+45(\mathrm{Na}) \text {. }
$$

Similarly, the flocculating charge is derived from the concentrations of the cations $\left(\mathrm{cmol}_{\mathrm{c}} \cdot \mathrm{kg}^{-1}\right.$ on soil basis) in the dispersed soil-water suspension, weighted by the respective flocculating power, and is defined as:

$$
\text { Flocculating charge }\left(\mathrm{cmol}_{\mathrm{c}} \cdot \mathrm{kg}^{-1}\right)=45(\mathrm{Ca})+27(\mathrm{Mg})+1.8(\mathrm{~K})+(\mathrm{Na}) \text {. }
$$

When the dispersive charge is above a threshold value, clay particles dissociate and form a diffuse double layer [19]. The flocculating effects of cations operate only when a diffuse double layer is developed. At lower dispersive charge, soil aggregates slake as macro aggregates break into micro aggregates; this process is not affected by the electrolyte concentration (i.e., salinity) of the soil solution [20].

If the flocculating charge contributed by the cations in a saline soil is equal to or greater than the dispersive charge, the soil structural effects of salinity will be minimal and crop growth is mainly affected by osmotic and ion toxicity effects. When the flocculating charge is lower than the dispersive charge, degradation of soil physical conditions will affect crop growth confounding the salt tolerance of crops (Figure 1). When the electrolyte concentration is low, cations do not reach toxic concentrations in the soil solution. For example, non-saline soils with high exchangeable sodium and low EC do not 
have toxic levels of sodium in soil solutions [1]. Thus, seasonal changes in salt concentration in the field will determine whether soil structural effect or salinity effect influence crop performance.

Because of the difficulties in the estimation of exchangeable cations, cations estimated in soil solution have been used to derive SAR to predict ESP and associated soil physical conditions. However, $\mathrm{K}$ is not included in the derivation of SAR and $\mathrm{Mg}$ is considered as equal to $\mathrm{Ca}$ in the SAR model. Rengasamy and Marchuk [9] have proposed the "cation ratio for soil structural stability (CROSS)" which is defined as follows:

CROSS $=(\mathrm{Na}+0.56 \mathrm{~K}) /(\mathrm{Ca}+0.6 \mathrm{Mg})^{0.5}$ where the concentrations of cations are expressed in $\mathrm{mmol} / \mathrm{L}$. CROSS includes the dispersive effects of $\mathrm{K}$ in relation to $\mathrm{Na}$, and the flocculating effect of $\mathrm{Mg}$ in relation to $\mathrm{Ca}$. CROSS has been found to be effective in predicting clay dispersion and soil physical behaviour, particularly when $\mathrm{K}$ and $\mathrm{Mg}$ are present in significant amounts in soils.

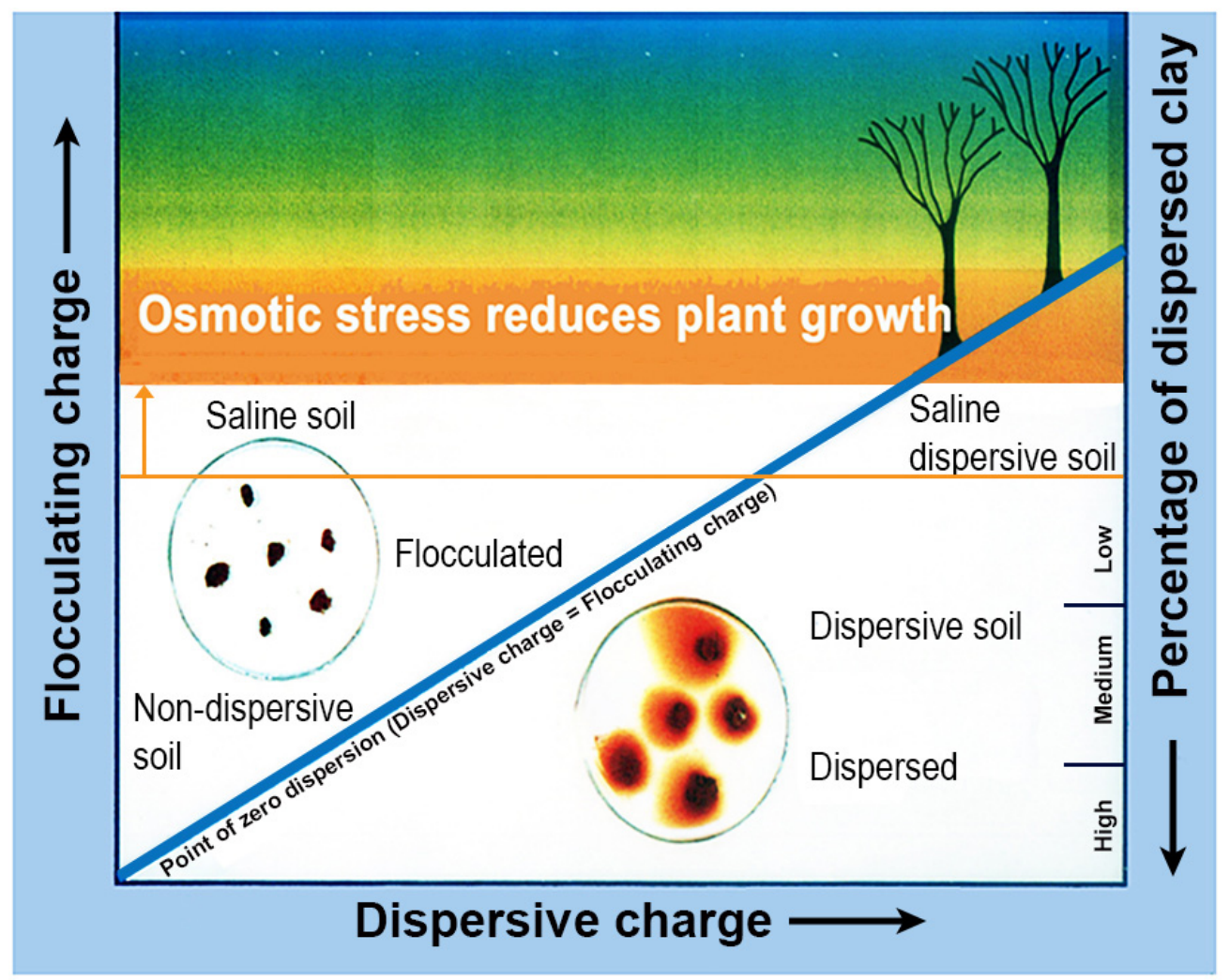

Figure 1. Schematic diagram distinguishing saline, saline-dispersive, and dispersive soils in relation to dispersive charge, flocculating charge, and the percentage of dispersed clay. Saline soils affect plant growth through ion toxicity and osmotic effect. Dispersive soils affect plant growth because of poor soil physical conditions. Combinations of these mechanisms are likely to be responsible for poor crop performance in saline-dispersive soils. Ion toxicity or imbalance depends on the concentration and composition of aqueous ions.

\section{Soil $\mathrm{pH}$ in Relation to Measurement Techniques}

The dissolved cations and anions react with water molecules producing hydrogen ions. The measurement of $\mathrm{pH}$ using electrodes indicates the activity of hydrogen ions rather than their concentration. Hydrolysis of water molecules by cations and anions changes the $\mathrm{pH}$ of soil solutions to be either acidic or alkaline [21]. In addition, ionic strength determined by the concentration and valence of the ions influences the activity of hydrogen ions. The ionic strength of a soil solution (affected by measurement in electrolyte solutions such as $\mathrm{CaCl}_{2}$ or highly saline soil solutions) can affect soil $\mathrm{pH}$ (e.g., [22]). In acidic soils, cations in electrolyte solutions can replace exchangeable $\mathrm{H}^{+}$or $\mathrm{Al}^{3+}$ which in soil solutions can decrease soil pH. However, in alkaline soils, with exchangeable $\mathrm{H}^{+}$ 
or $\mathrm{Al}^{3+}$ being absent, hydrolysis by anions or other cations contributes to the changes in $\mathrm{pH}$ due to electrolyte levels. Measuring $\mathrm{pH}$ in soil suspensions instead of soil-water extracts introduces the effect of liquid junction potential or Donnan membrane potential associated with soil colloids on hydrogen ion activity [23]. Acid producing biological reactions such as nitrification can increase hydrogen ions and also ionic strength. Increase in ionic strength in acidic soil solution can change $\mathrm{pH}$ without any appreciable change in titratable acidity [24]. Variations of $\mathrm{pH}$ in different soil-water ratios, such as 1:5, 1:1, or saturation extract, are associated with changes in ionic strength and the concentration of individual ions involved in hydrolysis. Thus, many factors have to be considered in the interpretation of measured soil $\mathrm{pH}$ values.

\section{Role of Cations and Anions in Soil $\mathrm{pH}$}

Hydrolysis of cations, anions, and organic substances with different functional groups play a vital role in the equilibrium of soil $\mathrm{pH}$. The acidic $\mathrm{pH}(<6)$ of highly weathered soils with low basic exchangeable cations like $\mathrm{Ca}^{2+}, \mathrm{Mg}^{2+}, \mathrm{K}^{+}$, and $\mathrm{Na}^{+}$arises mainly because of the hydrolysis of the cations $\mathrm{Fe}$ and $\mathrm{Al}$ [21]. By contrast, the soils of arid regions usually have alkaline $\mathrm{pH}(>7)$ and contain mainly $\mathrm{Ca}^{2+}, \mathrm{Mg}^{2+}, \mathrm{K}^{+}$, and $\mathrm{Na}^{+}$as exchangeable cations. Conventionally, these cations have been called base or base-forming cations, and hydrolysis of these cations is assumed to cause alkaline pH. Brady and Weil et al 2008 described them as "non-acid cations" different from acid cations such as $\mathrm{H}^{+}$and $\mathrm{Al}^{3+}$ [25]. Tavakkoli et al. 2015 showed that when a soil with $>90 \%$ exchangeable $\mathrm{Na}^{+}$ had near neutral $\mathrm{pH}$ when accompanying anions were $\mathrm{Cl}^{-}$and $\mathrm{SO}_{4}{ }^{2-}$ and alkaline $\mathrm{pH}(>8)$ when accompanying anions were $\mathrm{HCO}_{3}{ }^{-}$and $\mathrm{CO}_{3}{ }^{2-}$ [21]. The weak hydrolysis reactions of $\mathrm{Cl}^{-}$and $\mathrm{SO}_{4}{ }^{2-}$ result in a small change from neutral $\mathrm{pH}$. However, the hydrolysis of $\mathrm{HCO}_{3}{ }^{-}$and $\mathrm{CO}_{3}{ }^{2-}$ produce higher concentrations of $\mathrm{OH}^{-}$resulting in higher $\mathrm{pH}$. They also showed that by increasing the ionic strength of an alkaline soil ( $\mathrm{pH}$ 9.82) with $\mathrm{NaCl}$ that $\mathrm{pH}$ was reduced to 8.32 , whereas by increasing the ionic strength by adding $\mathrm{CaCl}_{2}$, $\mathrm{pH}$ was reduced below 8; the precipitation of $\mathrm{CO}_{3}{ }^{2-}$ as $\mathrm{CaCO}_{3}$ was also involved in $\mathrm{pH}$ decrease. Al-Busaidi and Cookson 2003 found a negative relationship between soil $\mathrm{pH}$ and salinity (EC) in soils in Oman, the main factor contributing to this inverse relationship being the presence of soluble $\mathrm{Ca}^{2+}$ ions [26]. Thus, saline-alkaline soils have lower $\mathrm{pH}$ compared to alkaline soils with low ionic strength. Therefore, it is necessary to measure electrolyte concentration and composition in the interpretation of soil $\mathrm{pH}$.

\section{Toxicity and Deficiency of Nutrient Elements in Relation to Soil pH}

Increasing salinity leads to accumulation of ions in the plant over a period of time and leads to ion toxicity or ion imbalance. However, soil $\mathrm{pH}$ determines the solubility, complexation, and precipitation of ionic species in soil solution affecting the ion uptake and also the root growth. Sposito 2008 has summarised the principal cationic species in relation to acidic or alkaline soil pH (Table 2). The distribution of dissolved ionic species in soil solution can be derived from their total concentrations, $\mathrm{pH}$, concentration of ligands, conditional stability constants for all possible complexes, and the expressions for the mass balance of each ion [8].

For example, at low soil $\mathrm{pH}(<5)$, the solubility of $\mathrm{Al}$ from clay minerals introduce toxic cationic hydroxy species of $\mathrm{Al}$ which mainly affect the root growth [27]. When soil $\mathrm{pH}$ increases to $>9, \mathrm{Al}$ forms soluble anionic species such as $\mathrm{Al}(\mathrm{OH})_{4}{ }^{-}$which also affects root growth [28]. By contrast, Al-organic complexes are not toxic to crops because they are not taken up by the roots. The adsorption and desorption of ionic species by soil clays depend on soil $\mathrm{pH}$ which influences the charge on clays and also on the ionic species, which can lead to either deficiency or toxicity of elements. Confounding the interpretation of salinity-boron interactions is the influence of the $\mathrm{pH}$ of the soil solution [29]. Thus, boron adsorption on a calcareous Entisol is highly enhanced above pH 9.2 [30], when boron deficiency can be encountered. When the $\mathrm{pH}$ exceeds 8 , the speciation of boron starts to progressively shift from boric acid $\mathrm{B}(\mathrm{OH})_{3}$ to anionic borate $\mathrm{B}(\mathrm{OH})_{4}{ }^{-}$. At lower soil $\mathrm{pH}$ values, boron availability in soil solutions may be high and may hence become toxic. Different categories of salt-affected soils 
based on EC, SAR, and $\mathrm{pH}$ have different effects on nutrient toxicity and deficiency, and these are summarised below in Table 3.

Table 2. Principal cationic species in soil solution in relation to $\mathrm{pH}$ [8].

\begin{tabular}{|c|c|c|}
\hline Cation & Acidic Soils & Alkaline Soils \\
\hline $\mathrm{Na}^{+}$ & $\mathrm{Na}^{+}$ & $\mathrm{Na}^{+}$ \\
\hline $\mathrm{Mg}^{2+}$ & $\mathrm{Mg}^{2+}$ & $\mathrm{Mg}^{2+}$ \\
\hline $\mathrm{Al}^{3+}$ & Al-organic complex, $\mathrm{Al}(\mathrm{OH})_{\mathrm{n}}{ }^{3-\mathrm{n}}$ & $\mathrm{Al}(\mathrm{OH})_{4}{ }^{-}$ \\
\hline $\mathrm{Si}^{4+}$ & $\mathrm{Si}(\mathrm{OH})_{4}$ & $\mathrm{Si}(\mathrm{OH})_{4}$ \\
\hline $\mathrm{K}^{+}$ & $\mathrm{K}^{+}$ & $\mathrm{K}^{+}$ \\
\hline $\mathrm{Ca}^{2+}$ & $\mathrm{Ca}^{2+}$ & $\mathrm{Ca}^{2+}, \mathrm{CaHCO}_{3}{ }^{+}$, Ca-organic complex \\
\hline $\mathrm{Cr}^{3+}$ & $\mathrm{CrOH}^{2+}$ & $\mathrm{Cr}(\mathrm{OH})_{4}^{-}$ \\
\hline $\mathrm{Cr}^{6+}$ & $\mathrm{HCrO}_{4}^{-}$ & $\mathrm{CrO}_{4}^{2-}$ \\
\hline $\mathrm{Mn}^{2+}$ & $\mathrm{Mn}^{2+}$ & $\mathrm{Mn}^{2+}, \mathrm{MnHCO}_{3}^{+}$ \\
\hline $\mathrm{Fe}^{2+}$ & $\mathrm{Fe}^{2+}$ & $\mathrm{FeCO}_{3}, \mathrm{Fe}^{2+}, \mathrm{FeHCO}_{3}{ }^{+}$ \\
\hline $\mathrm{Fe}^{3+}$ & $\mathrm{FeOH}^{2+}, \mathrm{Fe}(\mathrm{OH})_{3}, \mathrm{Fe}$-organic complex & $\mathrm{Fe}(\mathrm{OH})_{3}, \mathrm{Fe}$-organic complex \\
\hline $\mathrm{Ni}^{2+}$ & $\mathrm{Ni}^{2+}$ & $\mathrm{NiCO}_{3}, \mathrm{NiHCO}_{3}^{+}, \mathrm{Ni}^{2+}$ \\
\hline $\mathrm{Cu}^{2+}$ & Cu-organic complex & $\mathrm{CuCO}_{3}, \mathrm{Cu}$-organic complex \\
\hline $\mathrm{Zn}^{2+}$ & $\mathrm{Zn}^{2+}$ & $\mathrm{ZnHCO}_{3}{ }^{+}, \mathrm{Zn}^{2+}, \mathrm{Zn}$-organic complex \\
\hline $\mathrm{Mo}^{6+}$ & $\mathrm{HMoO}_{4}^{-}$ & $\mathrm{HMoO}_{4}^{-}, \mathrm{MoO}_{4}^{2-}$ \\
\hline $\mathrm{Cd}^{2+}$ & $\mathrm{Cd}^{2+}, \mathrm{CdCl}^{+}$ & $\mathrm{Cd}^{2+}, \mathrm{CdCl}^{+}, \mathrm{CdHCO}_{3}^{+}$ \\
\hline $\mathrm{Pb}^{2+}$ & $\mathrm{Pb}^{2+}, \mathrm{Pb}$-organic complex & $\mathrm{PbCO}_{3}, \mathrm{PbHCO}_{3}{ }^{+}$, Pb-organic complex \\
\hline
\end{tabular}

Table 3. Categories of salt-affected soils based on $\mathrm{EC}_{\mathrm{e}}(\mathrm{dS} / \mathrm{m}), \mathrm{SAR}_{\mathrm{e}}$, and $\mathrm{pH}_{1: 5}$ water of soil solutions and possible mechanisms of impact on plants. Toxicity, deficiency, or ion-imbalance due to various ions will depend on the ionic composition of soil solution [31]. $\mathrm{SAR}_{\mathrm{e}}>6$ denotes sodic soils with dispersive behaviour in the Australian classification [32]. EC, electrical conductivity; SAR, sodium adsorption ratio.

\begin{tabular}{|c|c|c|}
\hline Category of Saline Soil & Criteria & Possible Mechanisms \\
\hline Acidic-saline soil & $\mathrm{EC}_{\mathrm{e}}>4 ; \mathrm{SAR}_{\mathrm{e}}<6 ; \mathrm{pH}<6$ & $\begin{array}{l}\text { Osmotic effect; microelement }(\mathrm{Fe}, \mathrm{Al}, \mathrm{Mn}) \text { toxicity; } \\
\text { Sulphate toxicity at low } \mathrm{pH}\end{array}$ \\
\hline Neutral saline soil & $\mathrm{EC}_{\mathrm{e}}>4 ; \mathrm{SAR}_{\mathrm{e}}<6 ; \mathrm{pH} 6-8$ & $\begin{array}{l}\text { Osmotic effect; toxicity of dominant anion } \\
\text { or cation other than } \mathrm{Na}^{+}\end{array}$ \\
\hline Alkaline-saline soil & $\mathrm{EC}_{\mathrm{e}}>4 ; \mathrm{SAR}_{\mathrm{e}}<6 ; \mathrm{pH} 8-9$ & Osmotic effect; $\mathrm{HCO}_{3}{ }^{-}$and $\mathrm{CO}_{3}{ }^{2-}$ toxicity \\
\hline Highly alkaline-saline soil & $\mathrm{EC}_{\mathrm{e}}>4 ; \mathrm{SAR}_{\mathrm{e}}<6 ; \mathrm{pH}>9$ & $\begin{array}{l}\text { Osmotic effect; } \mathrm{HCO}_{3}^{-} \text {and } \mathrm{CO}_{3}{ }^{2-} \text { toxicity; } \\
\text { toxicity of microelements }(\mathrm{Fe}, \mathrm{Al}, \mathrm{Mn})\end{array}$ \\
\hline Acidic saline-sodic soil & $\mathrm{EC}_{\mathrm{e}}>4 ; \mathrm{SAR}_{\mathrm{e}}>6 ; \mathrm{pH}<6$ & $\begin{array}{l}\text { Osmotic effect; microelement }(\mathrm{Fe}, \mathrm{Al}, \mathrm{Mn}) \text { toxicity; } \\
\qquad \mathrm{Na}^{+} \text {toxicity }\end{array}$ \\
\hline Neutral saline-sodic soil & $\mathrm{EC}_{\mathrm{e}}>4 ; \mathrm{SAR}_{\mathrm{e}}>6 ; \mathrm{pH} 6-8$ & $\begin{array}{l}\text { Osmotic effect; } \mathrm{Na}^{+} \text {toxicity; toxicity } \\
\text { of dominant anion }\left(\mathrm{Cl}^{-} \text {or } \mathrm{SO}_{4}^{2-}\right)\end{array}$ \\
\hline Alkaline-saline sodic soil & $\mathrm{EC}_{\mathrm{e}}>4 ; \mathrm{SAR}_{\mathrm{e}}>6 ; \mathrm{pH} 8-9$ & $\begin{array}{c}\text { Osmotic effect; } \mathrm{Na}^{+} \text {toxicity; } \mathrm{HCO}_{3}^{-} \\
\text {and } \mathrm{CO}_{3}{ }^{2-} \text { toxicity }\end{array}$ \\
\hline Highly alkaline saline-sodic soil & $\mathrm{EC}_{\mathrm{e}}>4 ; \mathrm{SAR}_{\mathrm{e}}>6 ; \mathrm{pH}>9$ & $\begin{array}{l}\text { Osmotic effect; } \mathrm{Na}^{+} \text {toxicity; } \mathrm{HCO}_{3}{ }^{-} \text {and } \mathrm{CO}_{3}{ }^{2-} \\
\text { toxicity; microelement }(\mathrm{Fe}, \mathrm{Al}, \mathrm{Mn}) \text { toxicity; } \\
\text { Indirect effect due to soil structural problems; }\end{array}$ \\
\hline Acidic-sodic soil & $\mathrm{EC}_{\mathrm{e}}<4 ; \mathrm{SAR}_{\mathrm{e}}>6 ; \mathrm{pH}<6$ & $\begin{array}{l}\text { seasonal waterlogging can induce microelement } \\
\qquad(\mathrm{Fe}, \mathrm{Al}, \mathrm{Mn}) \text { toxicity; }\end{array}$ \\
\hline Neutral sodic soil & $\mathrm{EC}_{\mathrm{e}}<4 ; \mathrm{SAR}_{\mathrm{e}}>6 ; \mathrm{pH} 6-8$ & $\begin{array}{l}\text { Indirect effect due to soil structural problems; } \\
\text { seasonal waterlogging; } \mathrm{Na}^{+} \text {toxicity at high } \mathrm{SAR}_{\mathrm{e}} \\
\text { Indirect effect due to soil structural problems; }\end{array}$ \\
\hline Alkaline-sodic soil & $\mathrm{EC}_{\mathrm{e}}<4 ; \mathrm{SAR}_{\mathrm{e}}>6 ; \mathrm{pH} 8-9$ & $\begin{array}{l}\text { seasonal waterlogging; } \mathrm{Na}^{+} \text {toxicity at high } \mathrm{SAR}_{\mathrm{e}} \text {; } \\
\text { possible } \mathrm{HCO}_{3}{ }^{-} \text {and } \mathrm{CO}_{3}{ }^{2-} \text { toxicity }\end{array}$ \\
\hline Highly alkaline-sodic soil & $\mathrm{EC}_{\mathrm{e}}<4 ; \mathrm{SAR}_{\mathrm{e}}>6 ; \mathrm{pH}>9$ & $\begin{array}{l}\text { Indirect effect due to soil structural problems; } \\
\text { seasonal waterlogging; } \mathrm{Na}^{+} \text {toxicity at high } \mathrm{SAR}_{\mathrm{e}} \\
\qquad \mathrm{HCO}_{3}{ }^{-} \text {and } \mathrm{CO}_{3}{ }^{2-} \\
\text { toxicity; microelement }(\mathrm{Fe}, \mathrm{Al}, \mathrm{Mn}) \text { toxicity }\end{array}$ \\
\hline
\end{tabular}




\section{Soil Organic Matter and the Chemistry of Soil Solution}

Soil organic matter is important in improving soil qualities such as soil structure, soil fertility, and microbial activity. The functions of soil organic matter will vary according to different fractions viz. particulate organic carbon, humus organic carbon, resistant organic carbon, and dissolved organic carbon [33]. Organic matter can improve aggregate stability by decreasing dispersive charge by covalent boding with soil surface charge. Hydrophobic organic fractions can prevent water interaction (wettability) and prevent aggregate breakdown. However, simple organic molecules with negative charge can increase soil dispersivity, as observed when farmyard manures containing uronic acid are applied to salt-affected soils [34]. The presence of uncomplexed carboxylic acids can reduce soil $\mathrm{pH}$. Strong adsorption of $\mathrm{Fe}$ and $\mathrm{Al}$ species by organic matter can effectively reduce proton concentration $\left(\mathrm{H}^{+}\right)$in soil solution [35]. Dissolved organic carbon in soil solution is highly influenced by soil $\mathrm{pH}$; higher dissolution of organic carbon is observed in high $\mathrm{pH}$ soils containing $\mathrm{HCO}^{3}$ - and $\mathrm{CO}_{3}{ }^{2-}$ ions [21]. Charged fractions of organic matter can contribute to the anion or cation exchange capacity of soils in a similar manner to of clay minerals. Microbial decomposition of organic matter can releases a myriad of organic compounds into the soil solution, these include particularly important plant nutrient elements such as $\mathrm{N}, \mathrm{P}$, and $\mathrm{S}$.

\section{Dispersive Soils and Waterlogging}

The fertility of dispersive soils with low nutrient reserves is compounded both by the low supply of water and by the low supply of oxygen to roots in dispersive soil layers. When the top soils are dispersive, waterlogging or reduction in aeration porosity of these layers lead to ion toxicity and deficiency due to changes in electron and proton activities $(\mathrm{pE}$ and $\mathrm{pH})$ in an environment of degraded soil structure [18]. The redox status of a soil is described by the free electron activity, $\mathrm{pE}\left(-\log \left(\mathrm{e}^{-}\right)\right.$, where $\mathrm{e}^{-}$denotes electron), in conjunction with proton activity $(\mathrm{pH})$. The relationships of $\mathrm{pH}$ and $\mathrm{pE}$ control oxidized or reduced ionic species in soil solution. Free electron activity $(\mathrm{pE})$ at $\mathrm{pH} 7$ for some equilibrium chemical reactions under anoxic and suboxic conditions [36] in dispersive soils are given in Table 4. Waterlogging may affect microelement concentrations in soil solutions by changes in $\mathrm{pE}$, or it may affect plant roots through either changes in energy (ATP) supply or membrane integrity [37]. Under waterlogged conditions, Setter et al. 2009 found significant increases in shoot concentrations of $\mathrm{Mn}, \mathrm{Fe}, \mathrm{Na}, \mathrm{B}$, and $\mathrm{Al}$ above critical concentrations for toxicity in wheat growing soils in India and Australia [38]. The interaction between waterlogging and salinity increases the abiotic stress experienced by plants $[39,40]$. High dispersivity, high $\mathrm{pH}$, and the low biological activity encountered in alkaline dispersive soils are not conducive for either the accumulation of organic matter or its mineralization [21]. Poor leaching conditions in these soils lead to the accumulation of toxic elements such as boron [41].

Table 4. Free electron activity $(\mathrm{pE})$ at $\mathrm{pH} 7$ for some equilibrium chemical reactions under anoxic and suboxic conditions in dispersive soils [36].

\begin{tabular}{cc}
\hline Chemical Reactions & pE \\
\hline $\mathrm{O}_{2}+4 \mathrm{H}^{+}+4 \mathrm{e}^{-} \leftrightarrow 2 \mathrm{H}_{2} \mathrm{O}$ & 13.80 \\
$2 \mathrm{NO}_{3}^{-}+12 \mathrm{H}^{+}+10 \mathrm{e}^{-} \leftrightarrow \mathrm{N}_{2}+6 \mathrm{H}_{2} \mathrm{O}$ & 12.66 \\
$\mathrm{MnO}_{2}+4 \mathrm{H}^{+}+2 \mathrm{e}^{-} \leftrightarrow \mathrm{Mn}^{2+}+2 \mathrm{H}_{2} \mathrm{O}$ & 6.80 \\
$\mathrm{Fe}(\mathrm{OH})_{3}+3 \mathrm{H}^{+}+\mathrm{e}^{-} \leftrightarrow \mathrm{Fe}^{2+}+3 \mathrm{H}_{2} \mathrm{O}$ & -3.13 \\
$\mathrm{SO}_{4}^{2-}+10 \mathrm{H}^{+}+8 \mathrm{e}^{-} \leftrightarrow \mathrm{H}_{2} \mathrm{~S}+4 \mathrm{H}_{2} \mathrm{O}$ & -3.63 \\
$\mathrm{CO}_{2}+8 \mathrm{H}^{+}+8 \mathrm{e}^{-} \leftrightarrow \mathrm{CH}_{4}+2 \mathrm{H}_{2} \mathrm{O}$ & -4.14 \\
$\mathrm{~N}_{2}+8 \mathrm{H}^{+}+6 \mathrm{e}^{-} \leftrightarrow 2 \mathrm{NH}_{4}^{+}$ & -4.69 \\
$2 \mathrm{H}^{+}+2 \mathrm{e}^{-} \leftrightarrow \mathrm{H}_{2}$ & -7.00 \\
\hline
\end{tabular}




\section{Variations in Soil Water Content and Changes in Total Water Potential and Ionic Composition}

Under field conditions, particularly in dryland cropping with climatic variations, soil water content fluctuates depending on rainfall and evapotranspiration. The total water potential including matric and osmotic potentials will change proportionally to the salt concentration affected by soil water content. As the soil dries due to evapotranspiration, the salt concentration increases as does the osmotic pressure of soil water. Rengasamy 2010 has described a field study in South Australia where fluctuations in soil water content during the growing season led to variations in total water potential and how this caused the reduction in wheat yield [1]. Similarly, Setter et al. 2016 have detailed how changes in soil water regime influenced by rain affected the productivity of wheat and barley in dryland saline land in Western Australia [38]. Studies on yield response due to simultaneous changes in salt concentration and water content are rare. Scientists have attempted to predict yield response in relation to the subsurface solution salinity averaged spatially and temporally (e.g., [42]). Furthermore, the changes in ionic composition and exchangeable cation composition with changes in water content in the field have not been studied in detail. Wada and Otani 1998 [43] and Oster and McNeal 1971 [44] have attempted modelling of soil solution composition with variations in water content. Misra and Tyler 1999 have indicated the variations in nutrient contents influenced by changes in soil water content [45]. It has to be remembered that plants growing in soils necessarily respond to the actual soil solution concentration and composition and not to the values calculated from the extracts of salts at artificial soil water contents [46].

\section{Conclusions}

Crop salinity tolerance is compounded by a range of environmental factors including soil chemistry. Chemical processes such as solubility and ionic speciation dictated by the nature of cations and anions in saline soil solutions lead to nutrient deficiency or ion toxicity. Cation and anion interactions control soil $\mathrm{pH}$ and associated soil constraints to crops. Adsorption of cations from saline soil solutions affects soil structural stability and soil physical conditions indirectly affecting crop growth through changes in soil strength, aeration, porosity, movement of water and nutrients, and the $\mathrm{pH}-\mathrm{pE}$ relationship. Furthermore, under field conditions, fluctuating levels of soil water content not only alters the total salt concentration (osmotic potential) but also the composition of constituent cations and anions [1].

Combining soil chemistry induced stresses with salt concentration related stresses may explain some of the difficulties that plant breeders are having in the development of salt tolerant crops with high growth and yield in the field. The failure of laboratory-bred NaCl-tolerant cultivars to perform well under field conditions may reflect the effects of sodicity and alkalinity [47]. In the field, crops are routinely subjected to a combination of different abiotic stresses [48]. Thus, rather than investigating the phylogenetic distribution of tolerance to one particular stress, such as salinity, one should consider the distribution of tolerance to a range of environmental stresses [49]. Henderson and Gilliham 2015 have suggested, on the basis of molecular processes occurring in different cell types within plant roots [50], the identification of the "gatekeeper" cell type which plays a key role in tolerance to a particular stress. Future research programs should focus on tolerance to combinations of different stress conditions, particularly those that occur in field environment [48].

Acknowledgments: The author thanks the Grain Research and Development Corporation of Australia for the financial support (GRDC project UA 00159).

Conflicts of Interest: The author declares no conflict of interest. 


\section{References}

1. Rengasamy, P. Soil processes affecting crop production in salt-affected soils. Plant Funct. Biol. 2010, 37, 613-620. [CrossRef]

2. Maas, E.V. Crop Salt Tolerance. In Agricultural Salinity Assessment and Management; American Society of Civil Engineers: New York, NY, USA, 1990; pp. 262-304.

3. Munns, R.; Tester, M. Mechanisms of salinity tolerance. Ann. Rev. Plant Biol. 2008, 59, 651-681. [CrossRef] [PubMed]

4. Jurinak, J.J. The chemistry of salt-affected soils and waters. In Agricultural Salinity Assessment and Management; American Society of Civil Engineers: New York, NY, USA, 1990; pp. 42-63.

5. Tanji, K.K. Salinity in the Soil Environment. In Salinity-Environment-Plants-Molecules; Lauchli, A., Luttge, U., Eds.; Kluwer Academic Publishers: AA Dordrecht, The Netherlands, 2002; pp. 21-51.

6. Naidu, R.; Rengasamy, P. Ion interactions and constraints to plant nutrition in Australian sodic soils. Aust. J. Soil Res. 1993, 31, 801-819. [CrossRef]

7. Rengasamy, P.; Olsson, K.A. Sodicity and soil structure. Aust. J. Soil Res. 1991, 29, 935-952. [CrossRef]

8. Sposito, G. The Chemistry of Soils, 2nd ed.; Oxford University Press: New York, NY, USA, 2008; pp. 94-118.

9. Rengasamy, P. World salinization with emphasis on Australia. J. Exp. Bot. 2006, 57, 1017-1023. [CrossRef] [PubMed]

10. Oster, J.D.; Jayawardane, N.S. Agricultural Management of Sodic Soils. In Sodic Soils: Distribution, Properties, Management, and Environmental Consequences; Sumner, M.E., Naidu, R., Eds.; Oxford University Press: New York, NY, USA, 1998; pp. 125-147.

11. Arienzo, M.; Christen, E.W.; Jayawardane, N.S.; Quayle, W.C. The relative effects of sodium and potassium on soil hydraulic conductivity and implications for winery wastewater management. Geoderma 2012, 173-174, 303-310. [CrossRef]

12. Buelow, M.C.; Steenwerth, K.; Parikh, S.J. The effect of mineral-ion interactions on soil hydraulic conductivity. Agric. Water Manag. 2015, 152, 777-785. [CrossRef]

13. Oster, J.D.; Smith, C.J.; Sposito, G. Accounting for potassium and magnesium in irrigation water quality assessment. Calif. Agric. 2016, 70, 71-76. [CrossRef]

14. Rengasamy, P.; Marchuk, A. Cation ratio of soil structural stability (CROSS). Soil Res. 2011, 49, $280-285$. [CrossRef]

15. Zhang, X.C.; Norton, L.D. Effect of exchangeable Mg on saturated hydraulic conductivity, disaggregation and clay dispersion of disturbed soils. J. Hydrol. 2002, 260, 194-205. [CrossRef]

16. Rengasamy, P. Clay dispersion. In Soil Physical Measurement and Interpretation for Land Evaluation; McKenzie, N., Coughlan, K., Cresswell, H., Eds.; CSIRO Publishing, Collingwood: Victoria, Australia, 2002; Chapter 14; pp. 200-210.

17. Rengasamy, P.; Sumner, M.E. Processes Involved in Sodic Behaviour. In Sodic Soils: Distribution, Properties, Management, and Environmental Consequences; Sumner, M.E., Naidu, R., Eds.; Oxford University Press: New York, NY, USA, 1998; pp. 35-50.

18. Rengasamy, P.; Tavakkoli, E.; McDonald, G.K. Exchangeable cations and clay dispersion: Net dispersive charge, a new concept for dispersive soil. Eur. J. Soil Sci. 2016. [CrossRef]

19. Van Olphen, H. An Introduction to Clay Colloid Chemistry, 2nd ed.; John Wiley: New York, NY, USA, 1977.

20. Emerson, W.W. Emerson Dispersion Test. In Soil Physical Measurement and Interpretation for Land Evaluation; McKenzie, N., Coughlan, K., Cresswell, H., Eds.; CSIRO Publishing, Collingwood: Victoria, Australia, 2002; pp. 190-199.

21. Tavakkoli, E.; Rengasamy, P.; Smith, E.; McDonald, G.K. The effect of cation-anion interactions on soil pH and solubility of organic carbon. Eur. J. Soil Sci. 2015, 66, 1054-1062. [CrossRef]

22. Kissel, D.E.; Sonon, L.; Vendrell, P.F.; Isaac, R.A. Salt concentration and measurement of soil pH. Commun. Soil Sci. Plant Anal. 2009, 40, 179-187. [CrossRef]

23. White, R.E. Measurement of soil pH. J. Aust. Inst. Agric. Sci. 1969, 35, 3-15.

24. Sumner, M.E. Measurement of soil pH: Problems and solutions. Commun. Soil Sci. Plant Anal. 1994, 25, 859-879. [CrossRef]

25. Brady, N.C.; Weil, R.R. The Nature and Properties of Soils; Pearson Education, Inc.: Upper Saddle River, NJ, USA, 2008. 
26. Al-Busaidi, A.S.; Cookson, B. Salinity-pH relationships in calcareous soils. Agric. Mar. Sci. 2003, 8, 41-46.

27. Kopittke, P.M.; Menzies, N.W.; Wang, P.; Blamey, F.P.C. Kinetics and nature of aluminium rhizotoxic effects: A review. J. Exp. Bot. 2016. [CrossRef] [PubMed]

28. Brautigan, D.J.; Rengasamy, P.; Chittleborough, D.J. Aluminium speciation and phytotoxicity in alkaline soils. Plant Soil 2012, 360, 187-196. [CrossRef]

29. Smith, T.E.; Grattan, S.R.; Grieve, C.M.; Poss, J.A.; Lauchli, A.E.; Suarez, D.L. pH dependent salinity-boron interactions impact yield, biomass, evapotranspiration and boron uptake in broccoli (Brassica oleracea L.). Plant Soil 2013. [CrossRef]

30. Goldberg, S.; Glaubig, R.A. Boron adsorption on California soils. Soil Sci. Soc. Amer. J. 1986, 50, $1173-1176$. [CrossRef]

31. Greene, R.; Timms, W.; Rengasamy, P.; Arshad, M.; Cresswell, R. Soil and aquifer salinization: Toward an integrated approach for salinity management of groundwater. In Integrated Groundwater Management; Jakeman, A., Barreteau, O., Hunt, R.J., Rinaudo, J., Ross, A., Eds.; Springer International Publishing: Cham, Switzerland, 2016; Chapter 15; pp. 377-412.

32. Isbell, R.F. The Australian Soil Classification; CSIRO Publishing, Collingwood: Victoria, Australia, $1996 ;$ p. 143.

33. Murphy, B.W. Impact of soil organic matter on soil properties-A review with emphasis on Australian soils. Soil Res. 2015, 53, 605-635. [CrossRef]

34. Rengasamy, P. Soil Salinization. In Oxford Research Encyclopedia, Environmental Science; Oxford University Press: New York, NY, USA, 2016. [CrossRef]

35. Thomas, G.W. pH. In Encyclopedia of Soil Science; Lal, R., Ed.; Marcel Dekker, Inc.: New York, NY, USA, 2002; pp. 980-984.

36. Ponnamperuma, F.N. Effects of flooding on soils. In Flooding and Plant Growth; Kozlowski, T.T., Ed.; Academic Press: London, UK, 1984; pp. 9-45.

37. Setter, T.L.; Waters, I.; Sharma, S.K.; Singh, K.N.; Kulsreshta, N.; Yaduvanshi, N.P.S.; Ram, P.C.; Singh, B.N.; Rane, J.; Mcdonald, G.; et al. Review of wheat improvement for waterlogging tolerance in Australia and India: The importance of anaerobiosis and element toxicities associated with different soils. Ann. Bot. 2009, 103, 221-235. [CrossRef] [PubMed]

38. Setter, T.L.; Waters, I.; Stefanova, K.; Munns, R. Salt tolerance, date of flowering and rain affect the productivity of wheat and barley on rainfed saline land. Field Crops Res. 2016, 194, 31-42. [CrossRef]

39. Barrett-Lennard, E.G. The interaction between waterlogging and salinity in higher plants: Causes, consequences and implications. Plant Soil 2003, 253, 35-54. [CrossRef]

40. Mahrous, F.N.; Mikkelsen, D.S.; Hafez, A.A. Effect of salinity on the electro-chemical and chemical kinetics of some plant nutrients in submerged soils. Plant Soil. 1983, 75, 455-472. [CrossRef]

41. Rengasamy, P. Transient salinity and subsoil constraints to dryland farming in Australian sodic soils: An overview. Aust. J. Exp. Agric. 2002, 42, 351-361. [CrossRef]

42. Steppuhn, H.; Van Genuchten, Th.; Grieve, C.M. Root-zone salinity: II. Indices for tolerance in agricultural crops. Crop Sci. 2005, 45, 221-232. [CrossRef]

43. Wada, S.; Otani, T. Changes in cationic composition of soil solution associated with changes of water content: A numerical study. Soil Sci. Plant Nutr. 1998, 44, 237-244. [CrossRef]

44. Oster, J.D.; McNeal, B.L. Computation of soil solution composition variation with water content for desaturated soils. Soil Sci. Soc. Am. J. 1971. [CrossRef]

45. Misra, A.; Tyler, G. Influence of soil moisture on soil solution chemistry and concentrations of minerals in calcicoles Phleum pheleoids and Veronica spicata grown on a limestone soil. Ann. Bot. 1999, 84, 401-410. [CrossRef]

46. Salinity: Environment-Plants-Molecules; Lauchli, A.; Luttge, U. (Eds.) Kluwer Academic Publishers: AA Dordrecht, The Netherlands, 2002.

47. Bui, E. Possible role of soil alkalinity in plant breeding for salt-tolerance. Biol. Lett. 2013, 9, 20130566. Available online: http://dx.doi.org/10.1098/rsbl.2013.0566 (accessed on 8 August 2013). [CrossRef] [PubMed]

48. Mittler, R. Abiotic stress, the field environment and stress combination. Trends Plant Sci. 2006, 11, 15-19. [CrossRef] [PubMed] 
49. Bromham, L.; Saslis-Lagoudakis, H.; Bennett, T.H.; Flowers, T.J. Soil alkalinity and salt tolerance: Adapting to multiple stresses. Biol. Lett. 2013, 9, 20130642. Available online: http://dx.doi.org/10.1098/rsbl.2013.0642 (accessed on 12 July 2016). [CrossRef] [PubMed]

50. Henderson, S.W.; Gilliham, M. The "Gatekeeper" concept: Cell-Type specific molecular mechanisms of plant adaptations. In Molecular Mechanisms in Plant Adaptation; Laitinen, R.A.E., Ed.; John Wiley \& Sons, Inc.: Hoboken, NJ, USA, 2015; Chapter 4; pp. 83-115. [CrossRef]

(C) 2016 by the author; licensee MDPI, Basel, Switzerland. This article is an open access article distributed under the terms and conditions of the Creative Commons Attribution (CC-BY) license (http://creativecommons.org/licenses/by/4.0/). 